\title{
Elevated serum uric acid reduce heart damage in patients undergoing opern-heart surgery
}

A. Nikolić ${ }^{1}$, D. Mijalković ${ }^{2}$, A. Nikolić ${ }^{2}$, D. Kastratović ${ }^{3}$, D. Blagojević ${ }^{3}$, B. Davidović ${ }^{2}$, M. Spasić ${ }^{2}$

${ }^{1}$ Institute for cardiovascular disease "Dedinje" Belgrade

${ }^{2}$ Institute for biological research Department of Physiology

${ }^{3}$ Centre for clinical pharmacology Clinical Center of Serbia
Objectives: Peroxynitrite is species claimed to propagate ischemia/reperfusion damage. In this report levels of serum uric acid (UA), a peroxynitrite scavenger, are compared with creatine phosphokinase (CPK) in male patients before and after open-heart surgery in order to asses if increased levels of UA may protect heart from biochemical damage induced by peroxynitrite during the coronary by-pass grafting (CABG) intervention.

Methods: 45 male patients (16 carvedilol pretreated $(6.25 \mathrm{mg} /$ daily, during 6 weeks before surgery, mean age $55.3 \pm 1.7$ years, range $50-71$ ) and 29 patients without carvedilol pretreatment (mean age $58.3 \pm 1.4$ years, range 47-73) underwent elective CABG were examined. Study inclusion criteria were CABG performed on two and more coronary-vessels with aortic crossclamp during 30-40 minutes. For assessment of patients objective health status before operations EuroSCORE were used. Serum uric acid (UA) levels and creatine phosphokinase (CPK) were measured spectrophotometricaly by using a quantitative enzymatic assay.

Results: Carvedilol pretreated patients had higher amount of serum $U A(p<0.05)$ comparing to non-treated patients. During the surgical procedure patients are subjected to temporary ischemia due to transfer from corporeal to extracorporeal circulation. In this period of time the amount of $\mathrm{UA}$ decreased in carvedilol pretreated group $(406 \pm 46(\mathrm{t} 1)$ vs. $300 \pm 22 \mathrm{mmol} / \mathrm{L}$ (t2)) to the level of non-treated patients $(328 \pm 14$ (t1) vs. $322 \pm 18 \mathrm{mmol} / \mathrm{L}$. Carvedilol pretreated patients and non-treated patients had the same level of CPK at the beginning of the surgical procedure (t1) $(78 \pm 6$ vs. $83 \pm 13 \mathrm{U} / \mathrm{L})$ but lower increase $(\mathrm{p}<0.05)$ in CPK activity in carvedilol pretreated patients in respect to nontreated patients $(338 \pm 46$ vs. $644 \pm 103 \mathrm{U} / \mathrm{L})$ at the end of procedure (t2). Such results suggest that open heart surgery led to elevated CPK levels, but this effect was less pronounced in patients with higher level of $U A$.
Conclusions: Our results suggest possible role of UA in the protection from reperfusion injury. Increase of $U A$ before surgery may be beneficial factor during CABG procedure in patients treated with carvedilol by decreasing level of peroxynitrite as one of molecular causes of reperfusion injury. Our results showed influence of UA on CPK levels at the end of surgical procedure, indicating that increased levels of $\mathrm{UA}$ may protect heart from biochemical damage induced by peroxynitrite during the CABG intervention.

Key words: antioxidants, cardiovascular disease, creatin phosphokinase, oxidative stress, uric acid

\section{INTRODUCTION}

T $\mathrm{t}$ is well known that in patients undergoing the open1 heart surgery, in the coronary by-pass grafting (CABG) intervention, oxidative stress occurred ${ }^{1-3}$. Myocardial and endothelial damages are still widely debated problem during ischemia-reperfusion sequence in heart surgery. The critical problem associated with this procedure is linked with the series of events such as block of oxidative phosphorilation and the increase in nitric oxide (NO) and oxygen free radical production. In addition, significant complication arising from $\mathrm{CABG}$ is ischemia/reperfusion injury $(\mathrm{I} / \mathrm{R})$ and subsequent large number of free radicals are released, due to, among others, metabolism of xanthine oxidase, activation of neutrophils and catecholamine oxidati$\mathrm{on}^{3}$. Data also indicates that oxidative stress and endothelial damage are major events during $\mathrm{CABG}$, thus overwhelming the scavenging capacity of myocyte and preventing restoration of normal energy balance for $30 \mathrm{~min}$. after reperfusion. All these alterations have been extensively characterized under experimental conditions ${ }^{4}$, as well as peroxynitrite role in local and multisystem injury ${ }^{5}$ but there were a scarce data on their relationship at clinical level. 
Among the many well-known antioxidants, the role of uric acid (UA) in the antioxidant system was not established. Uric acid has been used in clinical practice as a marker of several metabolic disturbances, although until recently its antioxidant properties in vivo had not been considered. UA has much higher antioxidant capacity then other low molecular antioxidants ${ }^{6}$. Among the many beneficial characteristics, probably the most interesting is the capability of UA to scavenge peroxynitrite $\left(\mathrm{ONOO}^{-}\right) \mathrm{di}^{-}$ rectly $^{7}$. On the other hand, it is well known that $\mathrm{ONOO}^{-}$ has been implicated in the etiology of reperfusion injury and other cardiovascular disease ${ }^{8,9}$. Teng et al ${ }^{10}$ suggested that although xanthine dehydrogenase (XDH) conversion to a free radical-producing oxidase can serve as an important source of superoxide and hydrogen peroxide during $\mathrm{I} / \mathrm{R}$ sequence, urate formation by $\mathrm{XDH}$ may provide a significant antioxidant defense against peroxynitrite and related NO-derived oxidants. Skinner et al. ${ }^{11}$ showed the capability of UA not only to scavenge $\mathrm{ONOO}^{-}$but also to produce a vasoactive nitric oxide ( $\mathrm{NO}$ ) donor. Release of NO from nitrosated UA derivative following insults such as ischemia/reperfusion could minimize tissue injury and thereby constitute a previously uncharacterized role for UA in human physiology.

In this paper we examined how increased level in serum UA in patients pretreated with carvedilol undergoing open-heart surgery influences CPK levels, as the marker of tissue damage degree - both mechanical and biochemical, in CABG intervention.

\section{MATERIALS AND METHODOLOGY}

We studied 45 male patients (16 carvedilol pretreated patients, mean age 55.3 \pm 1.7 years, range 50-71, and 29 controls, mean age $58.3 \pm 1.4$ years, range $47-73$ ) underwent elective coronary artery bypass grafting (CABG). Study inclusion criteria were CABG performed on two and more coronary-vessels with aortic cross-clamp during 3040 minutes. For assessment of patients objective health status before operations we used EuroSCORE (European system for cardiac operative risk evaluation). EuroSCORE is a simple, objective and up-to-date system for assessing heart surgery, soundly based on one of the largest, most complete and accurate databases in European cardiac surgical history ${ }^{12}$. The clinical characteristics of elected patients are shown in Table 1. There was no operative mortality in this study. Written consent was obtained from each patient after formal information regarding participation in this study.

Patients were divided in two groups: 1) patients received preoperatively carvedilol $(6.25 \mathrm{mg}$ once per day) during six weeks before operation (16 patients) and 2) patients prepared for CABG without carvedilol therapy (29 patients). Vein blood was taken at two time points: (t1) before cross-clamp ( $2 \mathrm{~min}$. after heparin application) and (t2) $30 \mathrm{~min}$. after declamp (30 min. after reperfusion, e.g. 15-20 min. after heparin neutralization with protamine sulphate).

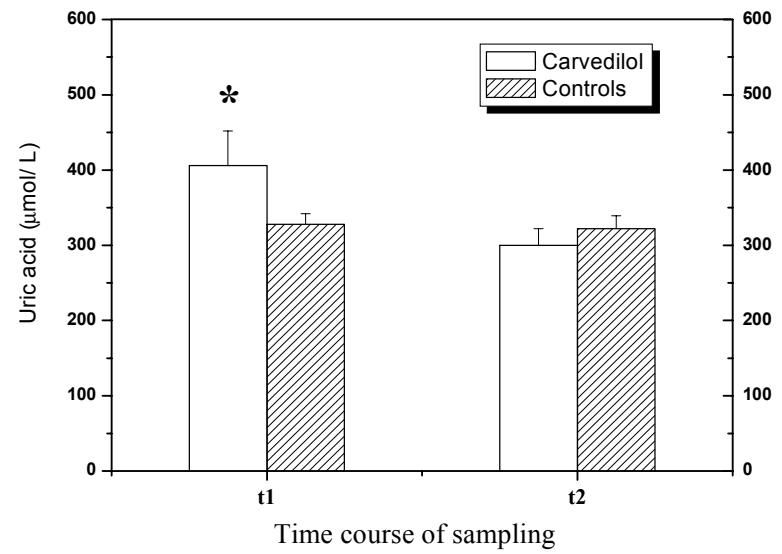

FIGURE 1

LEVELS OF URIC ACID (UDA) MEASURED BEFORE (T1) AND AFTER CROSS/CLAMP(T2). T1-2 MIN AFTER HEPARIN APPLICATION AND T2-30 MIN AFTER DECLAMP (30 MIN AFTER PERFUSSION, EG 15-20 MIN AFTER HEPARIN NEUTRALIZATION WITH PROTAMINE SULPHATE) RESULTS ARE EXPRESSED AS MEAN S.E.M. $(\mathrm{N}=16$ FOR CARVEDILOL PRETREATED PATIENTS, $\mathrm{N}=29$ FOR NON-TREATED PATIENTS)

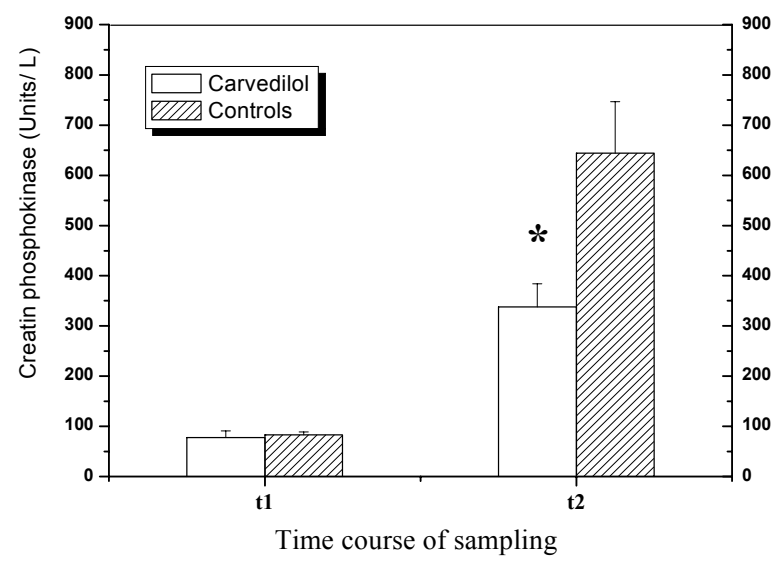

FIGURE 2

ACTIVITY OF CREATIN PHOSPHOKINASE (CPK) MEASURED BEFORE (T1) AND AFTER CROSS-CLAMP (T2). T12 MIN AFTER HEPARIN APPLICATION AND 72-30 MIN AFTER DECLAMP (30 MIN AFTER REPERFUSION, E.G. 15-20 MIN AFTER HEPARIN NEUTRALIZATION WITH PROTAMINE SULPHATE). RESULTS ARE EXPRESSED AS MEAN S.E.M (N=16 FOR CARVEDILOL PRETREATED PATIENTS, N=29 FOR NON-TREATED PATIENTS)

Serum uric acid (UA) levels and creatine phosphokinase (CPK) were measured on Shimadzu UV 260 spectrophotometer by using a quantitative enzymatic assay (BioSystems-Spain) according to the manufacturer's protocol. Results for UA were standardized by using standard solu- 
CLINICAL CHARACTERIZATION OF PATIENTS

\begin{tabular}{lcc}
\hline \multicolumn{1}{c}{ Characteristics } & Control group $(\mathrm{n}=29)$ & Carvedilol group $(\mathrm{n}=16)$ \\
\hline Mean age(years) & $58.2 \pm 11.4(47-73)$ & $55.3 \pm 11.7(50-71)$ \\
EuroSCORE & 2.92 & 4.67 \\
EF before /EF after CABG & $42.41 / 42.22$ & $32.14 / 31.07$ \\
Number of grafts per patients & $2.8 \pm 0.1$ & $2.9 \pm 0.2$ \\
\hline
\end{tabular}

TABLE 2

TWO-WAY ANALYSIS OF VARIANCE (ANOVA) FOLLOWED WITH SCHEFFE t-TEST OF INVESTIGATED GROUPS

\begin{tabular}{cccccc}
\hline & & Treatment (Tr) & Time $(\mathrm{T})$ & TrxT & Error \\
\hline \multirow{3}{*}{ UA } & df & 1 & 1 & 1 & 85 \\
& $\mathrm{MS}$ & 189002 & 53731 & 44002 & 10059 \\
& $\mathrm{~F}$ & 1.88 & $5.34^{*}$ & $4.37^{*}$ & \\
$\mathrm{CPK}$ & $\mathrm{dr}$ & 1 & 1 & 1 & 71 \\
& $\mathrm{MS}$ & 406327 & 2849312 & 382069 & 84085 \\
& $\mathrm{~F}$ & $4.83^{*}$ & $33.89 * * *$ & $4.54 *$ & \\
\hline
\end{tabular}

Effects:treatment (Tr), time (T) and interactions (Tr x T). Df - degree of freedom, MS - mean square and F - F value

tions of UA provided by manufacturer (BioSystemsSpain).

Data are presented as mean SEM. Comparisons between groups of patients were performed by Two-way ANOVA (treatment and time as effect) followed by Scheffe t-test. Values of $\mathrm{P}$ were considered significant.

\section{RESULTS}

In this study we demonstrated that elevated serum UA (in carvedilol pretreated patients) before the open-heart surgery had certain benefit effects for patients underwent open-heart surgery. Carvedilol pretreated patients had higher amount of serum UA $(\mathrm{p}<0.05)$ comparing to nontreated patients (Fig.1). During the surgical procedure patients are subjected to temporary ischemia due to transfer from corporeal to extracorporeal circulation. In this period of time the amount of UA decreased in carvedilol pretreated gro-up $(406 \pm 46(\mathrm{t} 1)$ vs. $300 \pm 22 \mathrm{mmol} / \mathrm{L}(\mathrm{t} 2))$ to the level of non-treated patients $(328 \pm 14$ (t1) vs. $322 \pm 18$ mmol/L (t2), significant difference between carvedilol pretreated patients and non treated and difference in time effect and interactions, Two way ANOVA, Scheffe t-test $\mathrm{p}<0.05$, Table 2.).

Carvedilol pretreated patients and non-treated patients had the same level of CPK at the beginning of the surgical procedure (t1) $(78 \pm 6$ vs. $83 \pm 13 \mathrm{U} / \mathrm{L})$ but lower increase $(\mathrm{p}>0.05)$ in CPK activity in carvedilol pretreated patients in respect to non-treated patients $(338 \pm 46$ vs. $644 \pm 103$ $\mathrm{U} / \mathrm{L}$ ) at the end of procedure (t2) (Fig.2, Table 2).
Such results suggest that open heart surgery led to elevated CPK levels, but this effect was less pronounced in patients with higher level of UA (significant time and treatment effect as well as their interactions, Two way ANOVA, Scheffe t-test $\mathrm{p}<0.05$, Table 2.).

Table 2. Two-way analysis of variance (ANOVA) followed with Scheffe t-test of investigated groups. Effects: treatment $(\mathrm{Tr})$, time $(\mathrm{T})$ and interactions $(\mathrm{Tr} x \mathrm{~T})$. Df - degree of freedom, MS - mean square and F- F value.

\section{DISCUSSION:}

Although urate was denoted as possible cardiovascular risk factor ${ }^{13}$ and its scavenger activity was reassessed by other researchers ${ }^{14}$ there are data that show its beneficial role in human physiology and pathophysiology. Best examples are application of urate in healthy volunteers ${ }^{15}$ which showed greater capacity of UA in scavenging free radicals than vitamin $\mathrm{C}$. This work also suggested, in view of UA antioxidant properties, that UA might have potentially important and beneficial effects within cardiovascular system. Other authors showed beneficial role of UA in treatment of experimental allergic encephalomyelitis ${ }^{16,17}$ and multiple sclerosis ${ }^{17,18}$.

Up to date it is well documented that cardiac surgery, especially cardiopulmonary bypass followed with extracorporeal circulation is accompanied with extensive oxidative stress $^{1-3,19}$ that aggravate postoperative prognosis for patients. In order to prevent oxidative stress in such patients different approaches were used. This includes application of free radical scavengers such as vitamin $C$, vitamin E, glutathione or different enzyme mimetic, or vari- 
ous enzyme inhibitors, but neither approach resolved the problem. Recently UA has attracted attention by its ability to scavenge peroxynitrite in direct reaction ${ }^{7}$.

Comparison of two groups of patients, carvedilol treated and non-treated showed that treated patients have higher level of UA (Fig.1, $\mathrm{p}<0.05$ ). This results further show that hi-gher endogenous urate was far more protective since tissue damage was less pronounced in carvedilol treated group (with higher level of UA) expressed through CPK activity $(\mathrm{p}<0.05)$. CPK is known to be a marker for heart tissue damage widely used in cardiology. Our results showed that although both group of patients were subjected to mechanical damage during surgery, biochemical damage (e.g. protein nitration due to peroxynitrite formation during ischemia, as well as subcellular damage due to free radical generation) was statistically lower in the group of patients with higher UA level, suggesting protective role of UA. Similar effects was observed by Teng et $\mathrm{al}^{7}$ who showed that urate produced during hypoxia protected heart proteins from peroxynitrite-mediated protein nitration and thus inactivation.

Skinner et al. ${ }^{11}$ showed that UA was considerably more susceptible to oxidation by $\mathrm{ONOO}^{-}$than other purines (hypoxanthine and xanthine). These authors also showed that some of the reaction products might have beneficial effects for patients. The product of the $\mathrm{UA} / \mathrm{ONOO}^{-}$reaction resulted in endothelium-independent vasorelaxation of rat thoracic aorta, with an $\mathrm{EC}_{50}$ value in the range of $0.03-0.3 \mathrm{mM}$. The UA nitration/nitrosation product may play a pivotal role in human pathophysiology by releasing $\mathrm{NO}$, which could decrease vascular tone, increase tissue blood flow, and thereby constitute a role for UA not previously described. The importance of nitrated UA product in such patients as well as other patients suffered from ischemia/reperfusion injury, acute myocardial infarction and other CVD is greater if we consider the fact that nominal potency of UA nitrated product is greater than NO donors used clinically, including glycerol trinitrate or amyl nitrite ${ }^{20}$.

Question of UA threshold concentration for reaction with peroxynitrite in vivo as our results show, may have answer in postulated reaction mechanism for UA - peroxynitrite reaction in vitro ${ }^{11}$ and alternative mechanism in vitro including UA reaction with NO previously transformed in to its redox congeniers - nitroxyl and nitrosonium ion ${ }^{21}$.

Contrary to present state of knowledge, increase of UA before surgery may be beneficial factor during $\mathrm{CABG}$ procedure in patients treated with carvedilol by decreasing level of peroxynitrite as one of molecular causes of reperfusion injury. Our results showed influence of UA on CPK levels at the end of surgical procedure, indicating that increased levels of UA may protect heart from biochemical damage induced by peroxynitrite during the $\mathrm{CABG}$ intervention. Even more, formation of nitrosative UA derivative by peroxynitrite may result in a formation of an vasoactive nitric oxide donor ${ }^{11}$ which may be beneficial in postoperative course of recovery in these patients.

\section{REZIME}

Ciljevi: Postoji mišljenje da Peroxynitrite širi - pojačava oštećenja koja potiču od ishemije/reperfuzije. U ovom radu poredjen je nivo mokraćne kiseline (UA) u serumu, sakupljača peroksinitrita, sa nivoom kreatin fosfokinaze (CPK) kod muškaraca pre i nakon operacije na otvo-renom srcu, a u cilju procene da li povećani nivoi UA mogu služiti kao zaštita od biohemijskih oštećenja izazvanih upotrebom peroksinitrita tokom hirurške CABG intervencije. Metode: Ispitivano je 45 bolesnika (16 je prethodno primalo karvedilol $-6.25 \mathrm{mg}$ dnevno, tokom 6 nedelja pre operacije, prosečne starosti $55.3 \pm 1.7$ godina, 55-71, i 29 bolesnika koji nisu primali karvedilol, prosečne starosti $58.3 \pm 1.4$ godina, 47-73) koji su bili podvrgnuti CABG hirurškoj intervenciji. Kriterijumi za uključenje u studiju su bili izvodjenje CABG na dva ili više sudova sa klemovanjem aorte u trajanju od $30-40$ minuta. Za procenu zdravstvenog stanja bolesnika pre operacije korišćen je EuroSCORE. Nivoi UA i kreatin fosfokinaze (CPK) u serumu su mereni uz pomoć spektrofotometrije korišćenjem kvantitativnog enzimskog eseja. Rezultati: U bolesnika koji su prethodno primali karvedilol uočeni su uvećani nivoi UA u serumu $(p<0.05)$ u poredjenju sa bolesnicima koji nisu primali pomenuti lek. Tokom hirurške procedure bolesnici su podvrgnuti privremenoj ishemiji zbog prebacivanja sa telesnog na vantelesni krvotok. U tom periodu vrednosti UA su snižene u bolesnika koji su prethodno primali karvedilol $(406 \pm 46(\mathrm{t} 1)$ naspram $300 \pm 22 \mathrm{~mol} / \mathrm{L}$ (t2)) bolesnika koji ga nisu primali (328 \pm 14 (t1) naspram $322 \pm 18 \mathrm{~mol} / \mathrm{L}$ ). Bolesnici koji su primali karvedilol i oni koji nisu imali su isti nivo CPK na početku hirurške procedure (t1) $(78 \pm 6$ naspram $83 \pm 13 \mathrm{U} / \mathrm{L})$ ali je na kraju procedure uočen niži porast aktivnosti CPK $(\mathrm{p}<0.05)$ u bolesnika koji su primali karvedilol u poredjenju sa bolesnicima koji nisu (338+46 prema $644 \pm 103 \mathrm{U} / \mathrm{L})(\mathrm{t} 2)$. Ovakvi rezultati sugerišu da intervencija na otvorenom srcu dovodi do povećanja nivoa CPK, ali je taj efekat bio manje izražen u bolesnika koji su imali viši nivo UA. Zaključak: Naši rezultati ukazuju na moguću pozitivnu ulogu mokraćne kiseline u zaštiti od oštećenja koja može prouzrokovati reperfuzija. Povećanje nivoa UA pre operacije može predstavljati koristan faktor tokom $\mathrm{CABG}$ procedure $\mathrm{u}$ bolesnika koji su primali karvedilol, jer snižava nivo peroksinitrita kao jedan od uzroka oštećenja od reperfuzije. Naši rezultati pokazuju uticaj UA na nivoe CPK pri kraju hirurške intervencije, što pak ukazuje na to da uvećani nivoi UA mogu štititi srce od biohemijskih oštećenja izazvana peroksinitritom tokom CABG intervencije.

Ključe reči: antioksidanti, oboljenja kardiovaskularnog sistema, kreatin fosfokinaza, oksidativni stres, mokraćna kiselina

\section{BIBLIOGRAFIJA}

1. Ochoa J.J., Vilchez M.J., Ibanez S., Huertas J.R., Palacio M.A. and Munoz-Hoyos A.. Oxidative stress is evident in erythrocytes as well as plasma in patients un- 
dergoing heart surgery involving cardiopulmonary bypass, Free Rad. Res. 2003; 37(1):11-17.

2. Ulus A.T., Aksoyek A., Ozkan M, Katircioglu S.F. and Basu S. Cardiopulmonary bypass as a cause of free radical-induced oxidative stress and enhanced bloodborne isoprostanes in humans, Free Rad. Biol. Med. 2003;34(7): 911-917.

3. Carlucci F., Tabucchi A., Biagoli B., Simeone F., Scolletta S., Rosi F. and Marinello E. Cardiac surgery: myocardial energy balance, antioxidant status and endothelial function after ischemia-reperfusion, Biomed. Pharmacother. 2002;56:483-491.

4. Cargnoni A., Ceconi C., Bernocchi P., Parrinello G., Benigno M., Boraso A., Curello S. and Ferrari R. Changes in oxidative stress and cellular redox potential during myocardial storage for transplantation: experimental studies, J. Heart Lung Transplant. 1999;18(5): 478-487.

5. Keith D.G., MacMillan-Crow L.A., Simovic M.O., Stain S.C. and May A.K. Pulmonary MnSOD is nitrated following hepatic ischemia-reperfusion, Surg Infect. 2004;5(2):166-173.

6. Buettner G.R. The pecking order of free radicals and antioxidants: lipid peroxidation, alpha-tocopherol, and ascorbate, Arch Biochem Biophys. 1993;300(2):535-43.

7. Santos C.X.C., Anjos E.I. and Augusto O. Uric acid oxidation by peroxynitrite: Multiple reactions, free radical formation and amplification of lipid oxidation, Arch. Biochem. Biophys. 1999;372(2):285-294.

8. Ferdinandy P. and Schultz R. Nitric oxide, superoxide, and peroxynitrite in myocardial ischemia-reperfusion injury and preconditioning, Br. J. Pharmacol. 2003 ; 138: 532-543.

9. Simovic M., Spasic M.B. and Michelson A,M. Free radicals in human myocardial reperfusion injury, Life Chem. Rep. 1995;12:227-270.

10. Teng R.J., Ye Y.Z., Parks D.A. and Beckman, J.S. Urate produced during hypoxia protects heart proteins from peroxynitrite-mediated protein nitration, Free Rad. Biol. Med. 2002;33(9):1243-1249.

11. Skinner K.A, White R.C, Patel R., Tan S., Barnes S., Kirk M., Darley-Usmar V. and Parks D.A. Nitrosation of uric acid by peroxynitrite. Formation of a vasoactive nitric oxide donor, J. Biol. Chem. 1998;273:24491-24497.

12. Nashef S.A.M., Roques F., Michel P., Gauducheau E., Lemeshow S. and Salamon R. European system for cardiac operative risk evaluation (EuroSCORE). Eur. J. Cardiothorac. Surg., 1999;16:9- 3.

13. Alderman M.H. Uric acid and cardiovascular ri- sk. Curr. Opin. Pharmacol., 2002;2(2):126-130.

14. Whiteman M., Ketsawatsakul U. and Halliwell B. A reassessment of the peroxynitrite scavenging activity of uric acid. Ann. N.Y.Acad. Sci., 2002;962:242-259.

15. Waring W.S., Webb D.J. and Maxwell S.R. Systematic uric acid administration increases serum antioxidant capacity in healthy volunteers. J. Cardiovasc. Pharmacol., 2001;38(3): 365-371.

16. Scott G.S., Spitsin S.V., Kean R.B., Mikheeva T., Koprowski H. and Hooper D.C. Therapeutic intervention in experimental allergic encephalomyelitis by administra- tion of uric acid precursors. Proc. Natl. Acad. Sci USA., 2002;99(25):16303-16308.

17. Hooper D.C., Spitsin S.V., Kean R.B., Champion J.M., Dickson G.M., Chaudhry I. and Koprowski H. Uric acid, a natural scavenger of peroxynitrite, in experimental allergic encephalomyelitis and multiple sclerosis. Proc. Natl. Acad. Sci. USA, 1998;95:675-680.

18. Koprowski H., Spitsin S.V. and Hooper D.C. Prospects for the treatment of multiple sclerosis by raising serum levels of uric acid, a scavenger of peroxynitrite. Ann. Neurol., 2000;49(1):139.

19. Lahet J.J., Courderot-Masuyer C., Lenfant F., Tatou E., Vergely C., David M. and Rochette L. The influence of extracorporeal circulation on the susceptibility of erythrocytes to oxidative stress. Free Rad. Res.,2004;38(7): 683-689.

20. White C.R., Moellering D., Patel R.P., Kirk M., Barnes S. and Darley-Usmar V. Formation of the NO donors glyceryl mononitrate and glyceryl mononitrite from the reaction of peroxynitrite with glycerol. Biochem. J., . 1997;328: 517-524.

21. Niketic V., Stojanovic S., Nikolic A., Spasic M.B. and Michelson A. M. Exposure of Mn and FeSODs, but not $\mathrm{Cu} / \mathrm{ZnSOD}$, to NO leads to nitrosonium and nitroxyl ions generation which cause enzyme modification and inactivation: an in vitro study. Free Rad. Biol. Med., 1999; 27(9-10): 992-996.

* Significant difference between treatment and controls, $\mathrm{p}<0.05$, Scheffe t-test.

* Significant difference between treatment and controls, p,Scheffe t-test. 